\title{
PENGARUH MOTIVASI DAN LINGKUNGAN KERJA TERHADAP KINERJA KARYAWAN PONDOK INDAH GOLF APARTMENT
}

\author{
Turmono \\ Email: turmono217@gmail.com \\ Program Studi Manajemen STIE Dharma Bumiputera
}

\begin{abstract}
ABSTRAK
Penelitian ini bertujuan untuk menguji dan menganalisis pengaruh motivasi dan lingkungan kerja terhadap kinerja karyawan Pondok Indah Golf Apartment. Penelitian ini menggunakan data primer yang diperoleh dari penyebaran kuesioner kepada karyawan Pondok Indah Golf Apartment. Metode analisis yang digunakan adalah regresi linier berganda yang dioperasikan melalui program SPSS 21. Hasil analisis, menunjukkan bahwa motivasi dan lingkungan kerja secara parsial berpengaruh positif dan signifikan terhadap kinerja karyawan.
\end{abstract}

Kata kunci: Motivasi, lingkungan kerja, kinerja karyawan

\section{ABSTRACT}

This research aims to test and analyze the influence of motivation and work environment on employee performance of Pondok Indah Golf Apartment. This research used primary data that obtained from questionnaires distribution to the employees Pondok Indah Golf Apartment. Analysis methode used was multiple linear regression that operated through SPSS 21 program. Results of the research showed that motivation and work environment partially has positive and significant influence on employee performance of Pondok Indah Golf Apatment.

Keywords: Motivation, work environment, employee performance

\section{PENDAHULUAN}

Seiring perkembangan zaman, tercipta persaingan antarperusahaan yang semakin ketat dan menuntut setiap perusahaan untuk memiliki karyawan yang berkualitas dalam rangka mendukung upayanya untuk menang dalam persaingan tersebut. Keberhasilan suatu perusahaan dalam mencapai tujuan secara dominan juga sangat dipengaruhi oleh kinerja karyawannya. Oleh sebab itu, faktor-faktor yang mempengaruhi kinerja karyawan sangat penting untuk diperhatikan.

Tingginya pertumbuhan penduduk menyebabkan bermunculannya berbagai perusahaan yang bergerak di bidang Properti dan Real Estate untuk memenuhi kebutuhan masyarakat atas tempat hunian. Pondok Indah Golf Apartment hadir untuk memenuhi kebutuhan masyarakat atas hunian berkelas di kawasan elit. Menghadapi ketatnya persaingan di sektor tersebut, Pondok Indah Golf Apartment senantiasa berupaya meningkatkan 
kinerjanya agar dapat menang di tengah persaingan tersebut. Dalam praktiknya, perusahaan dapat menggunakan berbagai variabel sebagai alat untuk meningkatkan kinerja karyawannya.

Salah satu faktor yang dapat mempengaruhi kinerja karyawan adalah motivasi kerja. Gustituati (2009) mengemukakan bahwa karyawan bermotivasi tinggi akan berkeinginan kuat untuk berhasil dalam bekerja, sehingga akan bekerja secara bersemangat, giat, tekun, bersungguh-sungguh, aktif, kreatif, dan bertanggung jawab serta mampu mengatasi kesulitan yang dihadapinya. Karyawan yang bersemangat dalam bekerja akan mampu meningkatkan kinerjanya dan berkontribusi secara maksimal terhadap perusahaan.

Sementara itu, karyawan yang tidak memperoleh imbalan kerja yang sesuai dengan harapannya cenderung akan menghasilkan output yang tidak maksimal karena menurunnya motivasi kerja. Hal tersebut terjadi karena tidak terpenuhinya kebutuhan karyawan akan menimbulkan dampak psikologi yang membuat motivasi kerja menurun dan kepuasan kerja tidak didapatkan. Karyawan yang kebutuhannya tidak terpenuhi oleh perusahaan, misalnya dalam bentuk gaji yang mencukupi, cenderung akan mencari pekerjaan sampingan di luar, sehingga seringkali tidak masuk kerja dengan berbagai alasan. Bentuk manifestasi lain dari turunnya motivasi kerja adalah turunnya komitmen dan kinerja karyawan.

Hasil penelitian yang dilakukan oleh Theodora (2015) dan Ayer, dkk. (2016) berhasil membuktikan bahwa motivasi berpengaruh positif dan signifikan terhadap kinerja karyawan. Akan tetapi, hasil penelitian yang dilakukan oleh Dhermawan, dkk. (2012) justru menunjukkan bahwa motivasi tidak berpengaruh signifikan terhadap kinerja karyawan.

Hasil penelitian yang dilakukan oleh Rahmawanti, dkk. (2014) serta Ningrum, dkk. (2014) menunjukkan bahwa kinerja karyawan juga dapat dipengaruhi oleh lingkungan kerja. Mardiana (2005) dalam Hendri (2012) mengemukakan bahwa lingkungan kerja yang kondusif akan membuat karyawan merasa aman, sehingga karyawan tersebut dapat bekerja secara optimal. Menurut Moekijat (2002:135), perusahaan dengan lingkungan kerja yang baik dan nyaman akan mendorong karyawan untuk meningkatkan kinerjanya. Penciptaan lingkungan kerja yang baik perlu dilakukan agar karyawan merasa diperhatikan dan diperlakukan sebagai bagian dari perusahaan, sehingga karyawan merasa nyaman dalam bekerja dan terdorong untuk menghasilkan kinerja yang baik sesuai tujuan perusahaan. Meskipun demikian, hasil penelitian yang dilakukan oleh Dhermawan, dkk. (2012) justru menunjukkan bahwa lingkungan kerja tidak berpengaruh signifikan terhadap kinerja karyawan. 
Adanya research gap sebagaimana yang telah diuraikan di atas menunjukkan bahwa perlu dilakukan suatu penelitian untuk menguji dan menganalisis pengaruh motivasi dan lingkungan kerja terhadap kinerja karyawan Pondok Indah Golf Apartment.

\section{TINJAUAN PUSTAKA}

\section{Motivasi}

Hasibuan (2014:141) menjelaskan bahwa motivasi berasal dari bahasa latin, yaitu "movere" yang berarti dorongan atau menggerakan. Menurut Hasibuan (2014), motivasi adalah pendayagerakkan kegairahan kerja seseorang agar mereka mau bekerja sama, bekerja efektif, dan berintegrasi untuk mencapai kepuasan. Adapun Bangun (2012:312) mendefinisikan motivasi sebagai kondisi yang mendorong orang untuk melaksanakan tugasnya sesuai dengan fungsinya di organisasi.

\section{Asas-Asas Motivasi}

Menurut Hasibuan (2014:146), motivasi memiliki asas-asas sebagai berikut.

1. Asas mengikutsertakan, yaitu asas yang mengajak karyawan untuk berpartisipasi dan memberi mereka kesempatan untuk memberikan ide dan saran dalam proses pengambilan keputusan.

2. Asas komunikasi, yaitu asas yang menginformasikan secara jelas mengenai tujuan, cara mencapainya, dan kendala dalam proses pencapaiannya.

3. Asas pengakuan, yaitu asas yang memberikan penghargaan dan pengakuan yang tepat serta wajar kepada karyawan atas prestasi kerjanya.

4. Asas wewenang dan delegasi, yaitu asas yang mendelegasikan wewenang dan kebebasan bagi karyawan untuk mengambil keputusan dan berkreasi.

5. Asas perhatian timbal balik, yaitu asas yang memotivasi karyawan dengan mengemukakan harapan perusahaan dan berupaya memenuhi kebutuhan yang diharapkan karyawan perusahaan.

\section{Metode Motivasi}

Menurut Hasibuan (2014:149), motivasi dapat dilakukan dengan dua metode berikut.

1. Motivasi langsung (direct motivation), yaitu motivasi (materil dan nonmateril) yang secara langsung diberikan kepada karyawan untuk memenuhi kebutuhan serta 
kepuasannya. Motivasi ini bersifat khusus, seperti pujian, penghargaan, tunjangan hari raya, bonus, dan bintang jasa.

2. Motivasi tidak langsung (indirect motivation), yaitu motivasi dengan memberikan fasilitas pendukung serta penunjang kelancaran dan gairah kerja, sehingga karyawan betah dan bersemangat dalam melaksanakan pekerjaannya.

\section{Jenis Motivasi}

Menurut Hasibuan (2014:150), motivasi terdiri dari dua jenis, yaitu sebagai berikut.

1. Motivasi positif, yaitu memotivasi dengan memberikan hadiah kepada karyawan yang berprestasi di atas standar.

2. Motivasi negatif, yaitu memotivasi dengan memberi hukuman kepada karyawan yang berprestasi di bawah standar.

\section{Proses Motivasi}

Menurut Hasibuan (2014:150), proses motivasi antara lain sebagai berikut.

1. Tujuan, yakni penetapan tujuan organisasi terlebih dahulu sebelum memotivasi karyawan ke arah tujuan itu.

2. Mengetahui kepentingan, yakni mengetahui keinginan karyawan dan tidak sekedar melihat dari sudut kepentingan pimpinan atau perusahaan saja.

3. Komunikasi efektif, yaitu pengkomunikasian kepada karyawan mengenai apa yang akan diperolehnya dan persyaratan yang perlu dipenuhinya untuk memperoleh insentif tersebut.

4. Integrasi tujuan, yaitu penyatuan motivasi untuk menyatukan tujuan organisasi dan kepentingan karyawan.

5. Fasilitas, yaitu memberikan fasilitas penunjang pekerjaan kepada karyawan.

6. Team work, yaitu kerja sama yang terkoordinasi baikuntuk mencapai tujuan perusahaan.

\section{Lingkungan Kerja}

Lingkungan kerja dapat diartikan sebagai seluruh sarana dan prasarana kerja di sekitar karyawan yang dapat mempengaruhi pelaksanaan pekerjaan, misalnya tempat bekerja, fasilitas, alat bantu pekerjaan, kebersihan, pencahayaan, ketenangan, dan hubungan kerja dengan orang-orang yang ada di tempat tersebut (Sutrisno 2010:118). .Menurut Robbins (2009:109), lingkungan merupakan keseluruhan kekuatan yang mempengaruhi penampilan suatu organisasi, sedangkan organisasi yang bersangkutan hanya memiliki sedikit 
kemampuan untuk mengandalkannya. Lingkungan kerja meliputi berbagai situasi di sekitar organisasi, baik lingkungan sosial (manusia) maupun lingkungan fisik (non manusia).

Sertain dalam Purwanto (2013:72), membagi lingkungan menjadi tiga bagian, yaitu sebagai berikut.

1. Lingkungan alam atau luar (external or physical environment), yaitu segala sesuatu di dalam dunia ini yang bukan manusia

2. Lingkungan dalam (internal environment), yaitu segala sesuatu yang termasuk ke dalam diri kita dan dapat mempengaruhi pertumbuhan fisik

3. Lingkungan sosial (social environment), yaitu semua orang yang mempengaruhi kita

\section{Faktor-Faktor yang Mempengaruhi Lingkungan Kerja}

Tyssen (2003) dalam Sofyan (2013:20) mengemukakan bahwa lingkungan kerja dipengaruhi oleh faktor-faktor berikut ini.

1. Fasilitas Kerja

Lingkungan kerja yang kurang mendukung pelaksanaan pekerjaan, seperti kurangnya ventilasi dan alat kerja, pengapnya ruang kerja, serta tidak jelasnya prosedur kerj, akan ikut menimbulkan kinerja yang buruk.

2. Gaji dan Tunjangan

Gaji yang tidak sesuai dengan pengharapan karyawan akan membuatnya cenderung berupaya untuk mencari pekerjaan lain yang mampu memenuhi harapan kerjanya.

3. Hubungan Kerja

Kelompok kerja yang kompak dan loyal akan turut meningkatkan kinerja karyawan karena setiap karyawan saling mendukung pencapaian tujuan dan/atau hasilnya masingmasing.

\section{Indikator Lingkungan Kerja}

Nitisemito (2000:127) dalam Nuraini (2013:97) mengemukakan bahwa lingkungan kerja memiliki indikator sebagai berikut.

1. Pencahayaan, yaitu penerangan yang cukup untuk pekerjaan yang memerlukan ketelitian tinggi.

2. Suhu udara, yaitu suhu udara yang pas untuk mempertahankan keadaan normal dari sistem di dalam tubuh karyawan.

3. Kebisingan, misalnya lingkungan kerja yang bising dapat mengganggu konsentrasi dalam melaksanakan pekerjaan. 
4. Tata ruang, yaitu tataan, warna dan kebersihan setiap ruangan yang akan mempengaruhi karyawan dalam melaksanakan pekerjaan.

5. Hubungan karyawan.

\section{Kinerja}

Robbins dalam Kasmir (2016:183) menyebutkan bahwa kinerja adalah fungsi interaksi antara kemampuan (ability), motivasi dan kesempatan (opportunity). Menurut Sedarmayanti (2013:260), kinerja adalah hasil kerja yang dicapai oleh karyawan sesuai dengan wewenang dan tanggung jawabnya dalam upaya mencapai tujuan perusahaan.

\section{Manfaat Penilaian Kinerja}

Menurut Bangun (2012:233), penilaian kinerja memiliki manfaat sebagai berikut.

a. Evaluasi Antarindividu dalam Organisasi

Hasil penilaian kinerja dapat digunakan sebagai bahan bagi manajemen dalam mempertimbangkan pemindahan pekerjaan (job transferring), promosi, mutasi atau demosi, hingga pemberhentian.

b. Pengembangan Diri Setiap Individu dalam Organisasi

Berdasarkan hasil penilaian kinerja, karyawan berkinerja rendah perlu mengembangkan dirinya melalui diklat.

c. Pemeliharaan Sistem

Penilaian kinerja dapat memelihara sistem di dalam organisasi melalui pengevaluasian pencapaian tujuan oleh karyawan, perencanaan sumber daya manusia, pengidentifikasian dan penetapan kebutuhan pengembangan organisasi, serta audit atas sistem sumber daya manusia.

d. Dokumentasi

Penilaian kinerja merupakan dasar pengambilan keputusan manajemen terhadap posisi pekerjaan, pemenuhan legalitas manajemen sumber daya manusia, dan kriteria pengujian validitas.

\section{Indikator Kinerja Karyawan}

Menurut Bangun (2012:233), kinerja karyawan dapat diukur dengan indikator berikut.

1. Kuantitas pekerjaan, yaitu jumlah pekerjaan yang dihasilkan karyawan sebagai syarat dari standar pekerjaan. 
2. Kualitas pekerjaan, yakni pemenuhan syarat tertentu untuk menghasilkan pekerjaan sesuai kualitas yang dituntutnya.

3. Ketepatan waktu, yaitu kemampuan untuk menyelesaikan pekerjaan secara tepat waktu sesuai karakteristik jenis pekerjaannya.

4. Kehadiran, yaitu tingkat kehadiran karyawan dalam melaksanakan pekerjaan sesuai tuntutan jenis pekerjaannya.

5. Kemampuan kerja sama, yaitu kemampuan untuk bekerja sama dengan rekan kerja dalam menyelesaikan jenis pekerjaan tertentu.

\section{Keterkaitan Antarvariabel Penelitian}

\section{Keterkaitan antara Motivasi Kerja dan Kinerja Karyawan}

Theodora (2015) dan Ayer, dkk. (2016) menemukan bahwa motivasi berpengaruh positif dan signifikan terhadap kinerja karyawan. Gustituati (2009) mengemukakan bahwa karyawan bermotivasi tinggi akan berkeinginan kuat untuk berhasil dalam bekerja, sehingga akan bekerja secara bersemangat, giat, tekun, bersungguh-sungguh, aktif, kreatif, dan bertanggung jawab serta mampu mengatasi kesulitan yang dihadapinya. Karyawan yang bersemangat dalam bekerja akan mampu meningkatkan kinerjanya dan berkontribusi secara maksimal terhadap perusahaan.

$\mathrm{H}_{1}$ : Motivasi kerja berpengaruh positif dan signifikan terhadap kinerja karyawan Pondok Indah Golf Apartment

\section{Keterkaitan antara Lingkungan Kerja dan Kinerja Karyawan}

Rahmawanti, dkk. (2014) serta Ningrum, dkk. (2014) menemukan bahwa lingkungan kerja berpengaruh positif dan signifikan terhadap kinerja karyawan. Mardiana (2005) dalam Hendri (2012) mengemukakan bahwa lingkungan kerja yang kondusif akan membuat karyawan merasa aman, sehingga karyawan tersebut dapat bekerja secara optimal. Menurut Moekijat (2002:135), perusahaan dengan lingkungan kerja yang baik dan nyaman akan mendorong karyawan untuk meningkatkan kinerjanya. Penciptaan lingkungan kerja yang baik perlu dilakukan agar karyawan merasa diperhatikan dan diperlakukan sebagai bagian dari perusahaan, sehingga karyawan merasa nyaman dalam bekerja dan terdorong untuk menghasilkan kinerja yang baik sesuai tujuan perusahaan.

$\mathrm{H}_{2}$ : Lingkungan kerja berpengaruh positif dan signifikan terhadap kinerja karyawan Pondok Indah Golf Apartment 


\section{Kerangka Analisis}

Berikut ini disajikan gambar kerangka analisis penelitian ini.

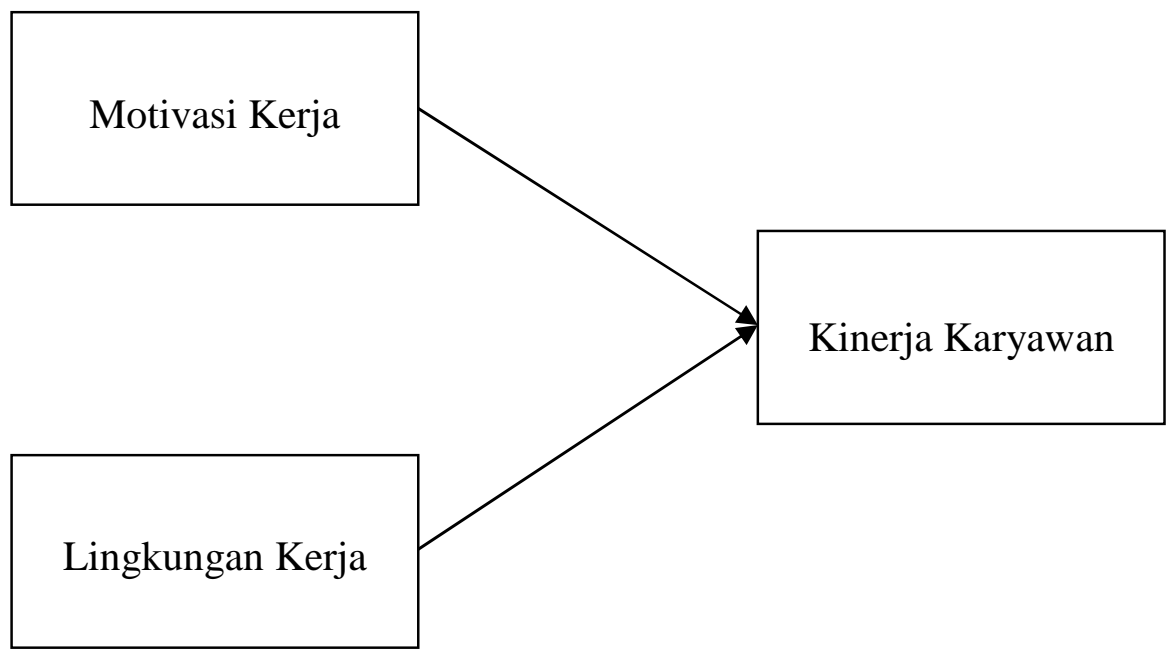

\section{Gambar 1. Kerangka Analisis}

\section{METODE PENELITIAN}

\section{Jenis dan Sumber Data}

Data yang digunakan dalam penelitian ini merupakan data cross section dan data primer yang diperoleh dari hasil pendistribusian kuesioner kepada responden.

\section{Populasi dan Sampel}

Populasi dalam penelitian ini adalah seluruh karyawan Pondok Indah Golf Apartment yang berjumlah 240 orang. Dari jumlah tersebut, diampil sampel penelitian sebanyak 71 orang.

\section{Definisi Operasional Variabel}

Berikut ini merupakan definisi operasional variabel-variabel dalam penelitian ini.

Tabel 1. Definisi Operasional Variabel

\begin{tabular}{|c|l|l|}
\hline Variabel & \multicolumn{1}{|c|}{ Definisi } & \multicolumn{1}{c|}{ Indikator } \\
\hline Motivasi Kerja & Suatu keadaan di dalam diri & 1. Kebutuhan fisiologis \\
& setiap karyawan Pondok Indah & 2. Kebutuhan rasa aman \\
& Golf Apartment yang & 3. Kebutuhan sosial \\
& mendorong mereka untuk & 4. Kebutuhan penghargaan diri \\
& melakukan pekerjaannya. & 5. Kebutuhan aktualisasi diri. \\
& & \multicolumn{2}{|c|}{ Sumber: Maslow (1943) dalam } \\
\end{tabular}




\begin{tabular}{|c|c|c|}
\hline $\begin{array}{c}\text { Lingkungan } \\
\text { Kerja }\end{array}$ & $\begin{array}{l}\text { Lingkungan di sekitar tempat } \\
\text { karyawan Pondok Indah Golf } \\
\text { Apartment bekerja }\end{array}$ & $\begin{array}{l}\text { 1. Pencahayaan } \\
\text { 2. Suhu udara } \\
\text { 3. Kebisingan } \\
\text { 4. Tata ruang } \\
\text { 5. Hubungan karyawan } \\
\text { Sumber: Nitisemito (2000) dalam } \\
\text { Nuraini (2013:97) }\end{array}$ \\
\hline $\begin{array}{c}\text { Kinerja } \\
\text { Karyawan }\end{array}$ & $\begin{array}{l}\text { Hasil kerja yang dicapai oleh } \\
\text { karyawan Pondok Indah Golf } \\
\text { Apartment dalam } \\
\text { melaksanakan pekerjaannya. }\end{array}$ & $\begin{array}{l}\text { 1. Jumlah pekerjaan } \\
\text { 2. Kualitas Pekerjaan } \\
\text { 3. Ketepatan waktu } \\
\text { 4. Kehadiran } \\
\text { 5. Kemampuan bekerja sama } \\
\\
\text { Sumber: Bangun }(2012: 233)\end{array}$ \\
\hline
\end{tabular}

\section{Metode Analisis}

Penelitian ini menggunakan metode analisis regresi linear berganda untuk menganalisis pengaruh motivasi dan lingkungan kerja terhadap kinerja karyawan Pondok Indah Golf Apartment.

\section{HASIL DAN PEMBAHASAN}

\section{Hasil Uji Validitas}

Hasil uji validitas menunjukkan bahwa seluruh pengukur di setiap variabel memiliki $r_{\text {hitung }}$ yang lebih besar daripada $r_{\text {tabel, }}$, sehingga alat ukur yang digunakan dalam penelitian ini terbukti valid.

\section{Hasil Uji Reliabilitas}

Hasil uji reliabilitas menunjukkan bahwa setiap variabel memiliki Cronbach Alpha yang lebih besar daripada 0,60 , sehingga semua variabel tersebut terbukti reliabel

\section{Hasil Uji Normalitas}

Berdasarkan hasil uji normalitas, diperoleh nilai Asymp. Sig. (2-tailed) sebesar 0,174 yang lebih besar daripada $\alpha=0,05$, sehingga data penelitian ini terbukti terrdistribusi normal.

\section{Hasil Uji Linieritas}

Berdasarkan hasil uji linieritas, setiap variabel motivasi dan lingkungan kerja memiliki nilai signifikansi secara berturut-turut sebesar 0,091dan 0,328 yang keduanya sama- 
sama lebih besar daripada 0,05 , sehingga dapat disimpulkan bahwa terdapat hubungan yang linier antara setiap variabel independen dengan variabel dependen.

\section{Hasil Uji Autokorelasi}

Berdasarkan hasil uji autokorelasi, diperoleh nilai Durbin Watson sebesar 1,755. Dengan 71 sampel $(\mathrm{n}=71)$, 2variabel independen $(\mathrm{k}=2)$ dan $\alpha$ sebesar 0,05 , diperoleh nilai $\mathrm{dL}$ sebesar 1,5577 dan dU sebesar 1,6733. Hal tersebut menunjukkan bahwa tidak ada autokorelasi dalam model penelitian ini karena telah memenuhi kriteria $\mathrm{dU}<\mathrm{DW}<4$-dU $(1,6733<1,755<4-1,6733)$.

\section{Hasil Uji Multikolinieritas}

Berdasarkan hasil uji multikolinearitas, setiap variabel independen memiliki nilai tolerance yang lebih besar daripada 0,1 dan nilai VIF yang lebih kecil daripada 10. Hal tersebut menunjukkan bahwa tidak terjadi multikolinearitas di dalam model penelitian ini.

\section{Hasil Uji Heteroskedastisitas}

Berdasarkan hasil uji heteroskedastisitas, setiap variabel independen memiliki nilai signifikansi yang lebih besar daripada 0,05 . Hal tersebut menunjukkan bahwa tidak terjadi heteroskedastisitas dalam model penelitian ini.

\section{Hasil Uji Regresi Linear Berganda}

Berdasarkan hasil uji regresi linear berganda, diperoleh persamaan regresi sebagai berikut.

$$
Y=22,943+0,268 X_{1}+0,301 X_{2}
$$

Keterangan:

$$
\begin{array}{ll}
\mathrm{Y} & =\text { Kinerja karyawan } \\
\mathrm{X}_{1} & =\text { Motivasi kerja } \\
\mathrm{X}_{2} & =\text { Lingkungan kerja }
\end{array}
$$

Pembahasan dari persamaan regresi liner berganda di atas adalah sebagai berikut.

a. Nilai konstanta sebesar 22,943 mengindikasaikan bahwa jika nilai variabel motivasi dan lingkungan kerja dianggap konstan, maka besarnya nilai kinerja karyawan Pondok Indah Golf Apartemen adalah 22,943. 
b. Nilai koefisien regresi variabel motivasi sebesar 0,268 menunjukkan bahwa peningkatan satu variabel motivasi dengan asumsi variabel bebas lain konstan akan menyebabkan kenaikan kinerja sebesar 0,268.

c. Nilai koefisien regresi variabel lingkungan kerja sebesar 0,301 menunjukkan bahwa peningkatan satu variabel lingkungan kerja dengan asumsi variabel bebas lain konstan akan menyebabkan kenaikan kinerja sebesar 0,301.

d. Jika terjadi peningkatan satu poin atas motivasi dan lingkungan kerja secara bersamasama, maka kinerja akan mengalami peningkatan sebesar 0,569. $(0,268+0,301)$.

\section{Hasil Uji Koefesien Determinasi}

Berdasarkan hasil pengujian, diperoleh koefesien determinasi $\left(\mathrm{R}^{2}\right)$ sebesar 0,392 . Hal tersebut menunjukkan bahwa motivasi dan lingkungan kerja berkontribusi sebesar 39,2\% dalam mempengaruhi kinerja karyawan, sedangkan $60,8 \%$ sisanya dipengaruhi oleh variabel lain yang tidak diteliti dalam penelitian ini.

\section{Hasil Uji F}

Berdasarkan hasil uji $\mathrm{F}$, diperoleh nilai $\mathrm{F}_{\text {hitung }}$ sebesar 21,891 dan nilai signifikansi sebesar 0,000. Sementara itu, besarnya $F_{\text {tabel }}$ pada tingkat kesalahan $5 \%, \mathrm{df}_{1}=(3-1)$ dan $\mathrm{df}_{2}=(71-3)$, adalah sebesar 3,13.

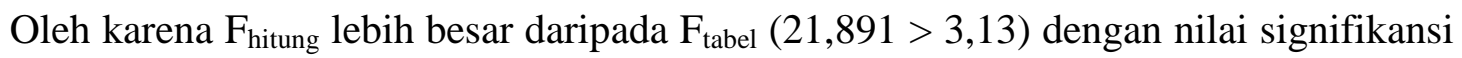
sebesar 0,000 yang lebih kecil daripada 0,05, maka motivasi dan lingkungan kerja secara simultan berpengaruh positif dan signifikan terhadap kinerja karyawan.

\section{Hasil Uji t (Parsial)}

Berdasarkan hasil uji t (parsial), setiap variabel independen dalam penelitian ini

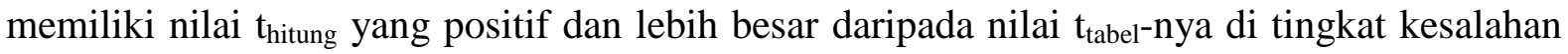
$5 \%$ dan df $=(71-2)$, serta memiliki nilai signifikansi yang lebih kecil daripada 0,05. Hal tersebut menunjukkan bahwa motivasi dan lingkungan kerja secara parsial berpengaruh positif dan signifikan terhadap kinerja karyawan Pondok Indah Golf Apartment.

\section{Pembahasan}

\section{Pengaruh Motivasi Kerja terhadap Kinerja Karyawan}

Penelitian ini membuktikan bahwa motivasi kerja berpengaruh positif dan signifikan terhadap kinerja karyawan Pondok Indah Golf Apartment. Hal tersebut menunjukkan bahwa 
semakin tinggi motivasi karyawan untuk bekerja, maka semkain tinggi kinerja karyawan tersebut. Sebaliknya, semakin rendah motivasi karyawan untuk bekerja, maka semakin rendah kinerja karyawan tersebut. Hal ini sejalan dengan hasil penelitian yang dilakukan oleh Theodora (2015) dan Ayer, dkk. (2016).

Gustituati (2009) mengemukakan bahwa karyawan bermotivasi tinggi akan berkeinginan kuat untuk berhasil dalam bekerja, sehingga akan bekerja secara bersemangat, giat, tekun, bersungguh-sungguh, aktif, kreatif, dan bertanggung jawab serta mampu mengatasi kesulitan yang dihadapinya. Karyawan yang bersemangat dalam bekerja akan mampu meningkatkan kinerjanya dan berkontribusi secara maksimal terhadap perusahaan.

Sementara itu, karyawan yang tidak memperoleh imbalan kerja yang sesuai dengan harapannya cenderung akan menghasilkan output yang tidak maksimal karena menurunnya motivasi kerja. Hal tersebut terjadi karena tidak terpenuhinya kebutuhan karyawan akan menimbulkan dampak psikologi yang membuat motivasi kerja menurun dan kepuasan kerja tidak didapatkan. Karyawan yang kebutuhannya tidak terpenuhi oleh perusahaan, misalnya dalam bentuk gaji yang mencukupi, cenderung akan mencari pekerjaan sampingan di luar, sehingga seringkali tidak masuk kerja dengan berbagai alasan. Bentuk manifestasi lain dari turunnya motivasi kerja adalah turunnya komitmen dan kinerja karyawan.

\section{Pengaruh Lingkungan Kerja terhadap Kinerja Karyawan}

Penelitian ini membuktikan bahwa lingkungan kerja berpengaruh positif dan signifikan terhadap kinerja karyawan Pondok Indah Golf Apartment. Hal tersebut menunjukkan bahwa semakin baik lingkungan di sekitar tempat karyawan bekerja, maka semkain tinggi kinerja karyawan tersebut. Begitupun sebaliknya. Hal ini sejalan dengan hasil penelitian yang dilakukan oleh Rahmawanti, dkk. (2014) serta Ningrum, dkk. (2014).

Mardiana (2005) dalam Hendri (2012) mengemukakan bahwa lingkungan kerja yang kondusif akan membuat karyawan merasa aman, sehingga karyawan tersebut dapat bekerja secara optimal. Menurut Moekijat (2002:135), perusahaan dengan lingkungan kerja yang baik dan nyaman akan mendorong karyawan untuk meningkatkan kinerjanya. Penciptaan lingkungan kerja yang baik perlu dilakukan agar karyawan merasa diperhatikan dan diperlakukan sebagai bagian dari perusahaan, sehingga karyawan merasa nyaman dalam bekerja dan terdorong untuk menghasilkan kinerja yang baik sesuai tujuan perusahaan. 


\section{KESIMPULAN DAN SARAN}

\section{Kesimpulan}

Berdasarkan hasil penelitian ini, dapat disimpulkan hal-hal berikut.

1. Motivasi kerja berpengaruh positif dan signifikan terhadap kinerja karyawan Pondok Indah Golf Apartment.

2. Lingkungan kerja berpengaruh positif dan signifikan terhadap kinerja karyawan Pondok Indah Golf Apartment.

\section{Saran}

Berdasarkan kesimpulan di atas, berikut ini dikemukakan beberapa saran.

1. Dalam rangka meningkatkan kinerja karyawannya, Pondok Indah Golf Apartment diharapkan dapat meningkatkan motivasi kerja karyawannya, misalnya melalui perbaikan jaminan asuransi, sistem jaminan asuransi keselamatan kerja, dan sebagainya.

2. Dalam rangka meningkatkan kinerja karyawannya, Pondok Indah Golf Apartment diharapkan dapat mengembangkan lingkungan di sekitar tempat karyawannya bekerja, misalnya melalui pengadaan, perbaikan dan pengembangan sarana dan prasarana kerja.

3. Dalam meneliti kinerja karyawan, peneliti selanjutnya diharapkan dapat menggunakan berbagai variabel bebas lainnya seperti gaya kepemimpinan, budaya organisasi, kompensasi, pelatihan, pengembangan, pendidikan.

\section{DAFTAR PUSTAKA}

Ayer, J.E., L.R.J. Pangemanan dan Y.P.I. Rori. 2016. Pengaruh Motivasi dan Disiplin Kerja terhadap Kinerja Pegawai pada Dinas Pertanian Kabupaten Supiori. Agri-Sosio Ekonomi Unsrat. 12(3A): 27-46.

Bangun, W. 2012. Manajemen Sumber Daya Manusia. Erlangga. Jakarta.

Dhermawan, A.A.N.B., I.G.A. Sudibya dan I.W.M. Utama. 2012. Pengaruh Motivasi, Lingkungan Kerja, Kompetensi dan Kompensasi terhadap Kepuasan Kerja dan Kinerja Pegawai di Lingkungan Kantor Dinas Pekerjaan Umum Provinsi Bali. Jurnal Manajemen, Stategi Bisnis dan Kewirausahaan. 6(2): 173-184.

Gustituati, N. 2009. Manajemen Pendidikan Landasan Teori dan Perkembangannya. UNP Press. Padang.

Hasibuan, M.S.P. 2014. Manajemen Sumber Daya Manusia.Bumi Aksara. Jakarta.

Hendri, E. 2012. Pengaruh Lingkungan Kerja Fisik dan Non Fisik terhadap Kepuasan Kerja Karyawan pada PT Asuransi Wahana Tata Cabang Palembang. Jurnal Media Wahana Ekonomika. 9(3): 1-16. 
Kasmir. 2016. Manajemen Sumber Daya Manusia: Teori dan Praktik. RajaGrafindo Persada. Jakarta.

Mardiana. 2005. Manajemen Produksi. IPWI. Jakarta.

Moekijat. 2002. Dasar-Dasar Motivasi. Pionir Jaya. Bandung.

Ningrum, N.L., A. Prasetya dan M.F. Riza. 2014. Pengaruh Lingkungan Kerja terhadap Kinerja Karyawan: Studi pada Karyawa Auto 2000 Sukun Malang. Jurnal Administrasi Bisnis. 11(1).

Nitisemito, A.S. 2000. Manajemen Personalia. Ghalia Indonesia. Jakarta.

Nuraini, T. 2013. Manajemen Sumber Daya Manusia. Yayasan Aini Syam. Pekan Baru.

Purwanto. 2013.Evaluasi hasil belajar. Pustaka Pelajar. Yogyakarta.

Rahmawanti, N.P., B. Swasto dan A. Prasetya. 2014. Pengaruh Lingkungan Kerja terhadap Kinerja Karyawan: Studi pada Karyawan Kantor Pelayanan Pajak Pratama Malang Utara. Jurnal Administrasi Bisnis. 8(2).

Robbins, S.P. 2009. Perilaku Organisasi. Salemba Empat. Jakarta.

Sofyan, D.K. 2013. Pengaruh Lingkungan Kerja terhadap Kinerja Kerja Pegawai BAPPEDA. Malikussaleh Industrial Engineering Journal. 2(1): 18-23.

Sutrisno, E. 2010. Manajemen Sumber Daya Manusia. Kencana Prenada Media. Jakarta.

Theodora, O. 2015. Pengaruh Motivasi Kerja terhadap Kinerja Karyawan PT Sejahtera Motor Gemilang. AGORA. 3(2): 187-195.

Tyssen, T.G. 1992. The First Time Manager: A Survival Gude. Self-Counsel Press. North Vancouver. Terjemahan A.H. Pudjaatmaka. 2003. Buku Petunjuk bagi Manajer Pemula. Arcan. Jakarta. 